\title{
Konstruktivisme dan Pembelajaran IPA
}

\author{
Agus Hariyadi Suprianto \\ SMP Negeri 1 Sine Ngawi \\ Agusrizki678@gmail.com
}

\begin{abstract}
Abstrak
Pada dasarnya konstruktivisme mengandung lima prinsip tentang belajar dan mengajar, yaitu: pertama, pembelajar telah memiliki pengetahuan awal; kedua, belajar merupakan proses pengkonstruksian pengetahuan berdasarkan pengetahuan awal yang telah dimiliki; ketiga, belajar adalah perubahan konsepsi pembelajar, keempat, proses pengkonstruksian pengetahuan berlangsung dalam konteks tertentu; dan kelima, pembelajar bertanggung jawab terhadap proses belajarnya. Banyak variasi konstruktivisme dan juga pandangan tentang bagaimana lingkungan pembelajaran dan urutan pembelajaran yang sesuai dengan prinsip-prinsip konstruktivisme. Untuk itu perlu dukungan khusus bagi para guru, misalnya melalui pendidikan dan pelatihan, serta forum berbagi pengalaman agar mereka dapat menerapkan prinsip-prinsip konstruktivisme dalam melaksanakan proses pembelajaran.
\end{abstract}

Kata kunci: konstruktivisme, pembelajaran, prinsip-prinsip, IPA, variasi

\section{PENDAHULUAN}

Sejak tahun 1980an konstruktivisme banyak mendominasi literatur tentang penelitian pendidikan IPA (Duit \& Treagust, 1998; White, 1997). Walaupun di Indonesia popularitas konstruktivisme tidak terlalu mencolok, namun dalam dokumen resmi kurikulum sekolah (Depdiknas, 2003a, 2003b) konstruktivisme secara eksplisit dinyatakan sebagai salah satu prinsip yang harus diperhatikan dalam pembelajaran biologi dan IPA. Meskipun demikian dalam dokumen kurikulum tidak dirinci lebih lanjut tentang apa dan bagaimana pembelajaran yang menerapkan prinsip-prinsip konstruktivisme.

Tulisan ini memaparkan pengertian konstruktivisme, mulai dari pemunculan, perkembangan, berbagai variasi, prinsipprinsip dasar, serta penerapannya dalam pembelajaran. Tulisan ini diharapkan dapat menjadi rujukan awal bagi pembaca dalam memahami konstruktivisme. Pemahaman yang baik mengenai konstruktivisme pada gilirannya diharapkan dapat menjadi pendorong untuk menerapkan prinsip-prinsip konstruktivisme dalam pembelajaran.

\section{KAJIAN PUSTAKA DAN PEMBAHASAN}

Kemunculan konstruktivisme sangat terkait erat dengan sebuah artikel yang ditulis oleh Driver dan Easley (1978). Dalam artikelnya, Driver dan Easley (1978) menegaskan bahwa prakonsepsi yang dimiliki anak-anak dari berbagai belahan dunia ternyata konsisten dan bahwa prakonsepsi anak sulit berubah. Anak tidak akan begitu saja berubah prakonsepsinya sekalipun ditunjukkan bukti-bukti yang menunjukkan bahwa prakonsepsi yang dimilikinya tidak tepat. Dalam artikel tersebut juga dimunculkan kata "constructivist" yang sebelumnya pernah digunakan oleh Popper untuk menggambarkan bahwa pertumbuhan IPA merupakan konstruksi mental berdasarkan intuisi. Penggunaan kata"constructivist" 
inilah yang dianggap oleh Solomon (1994) sebagai kunci munculnya konstruktivisme

Gambaran di atas menunjukkan bahwa kontruktivisme bukanlah suatu ide yang muncul dengan tiba-tiba. Konstruktivisme merupakan sebuah ide yang berkembang secara bertahap melalui sebuah proses evolusi yang panjang. Sebagai konsekuansi, konstruktivisme dalam kondisi yang sekarang bukanlah bentuk yang terakhir. Konstruktivisme mungkin saja masih akan terus berkembang menjadi bentuk-bentuk baru atau paling tidak memunculkan variasivariasi baru. Review tentang perkembangan konstruktivisme sejak kemunculannya pada akhir tahun 1970an menunjukkan bahwa konstruktivisme yang tadinya lebih berorientasi pada prinsip-prinsip kognisi menurut Piaget dan kognitivis kemudian bergeser menuju konstruktivisme sosial dan multi perspektif (Duit, 2002).

Pada tahun 1970an dan tahun 1980an, fokus utama penelitian dan tulisan tentang konstruktivisme berkisar pada konsepsi siswa tentang suatu fenomena dan strategi untuk mengubah konsepsi tersebut (lihat Gambar 1).

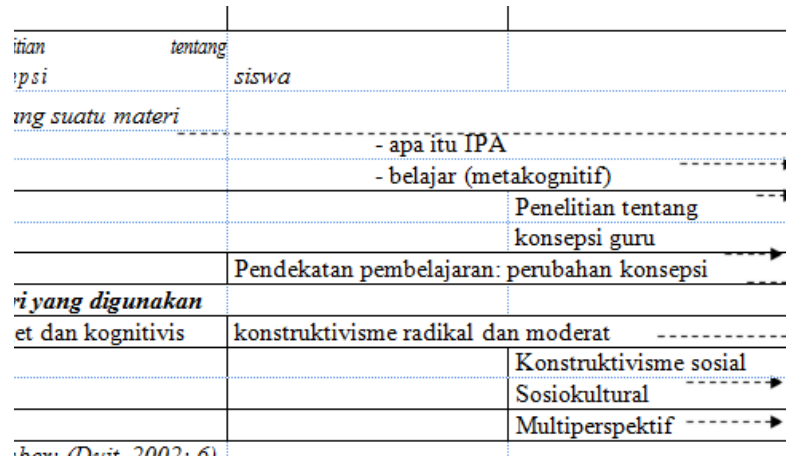

Gambar 1 Perkembangan penelitian yang didasarkan pada konstruktivisme

\footnotetext{
Konstruktivisme juga mendapatkan banyak kritik, terutama terhadap konstruktivisme radikal (akan dibahas pada bagian berikut). Beberapa kritik antara lain menyebutkan bahwa konstruktivisme tidak dikenal dalam leksikon filsafat (Howe \&
}

Berv, 2000), bahwa konstruktivisme tidak masuk akal, membingungkan dan tidak mempunyai dasar (Suchting, 1998), bahwa konstruktivisme menyesatkan dan merupakan pandangan yang tidak lengkap (Fox, 2001). Sebuah analisis yang dilakukan oleh Jenkins (2000) menyatakan bahwa konstruktivisme bukanlah sebuah model yang tepat untuk menggambarkan cara mengubah konsepsi sebagaimana yang dikatakan pendukungnya, namun konstruktivisme juga bukan pemikiran yang berbahaya sebagaimana yang disampaikan pengkritiknya.

\section{Variasi konstruktivisme}

$\begin{array}{ccc}\text { Literatur tentang } & \text { konstruktivisme } \\ \text { sangat bervariasi sehingga bisa }\end{array}$
membingungkan bagi pembacanya. Hal ini terjadi karena penulis menggunakan istilah yang sama untuk sesuatu yang berbeda ataupun sebaliknya menggunakan istilah yang berbeda untuk sesuatu yang sama. Berikut ilustrasi tentang kompleksitas dan variasi konstruktivisme.

- Good, Wandersee dan Julien (1993) mengidentifikasi bahwa ada 15 kata yang sering dikaitkan dengan konstruktivisme, yaitu: kontekstual (contextual), dialektis (dialectical), empiris (empirical), humanistik (humanistic), pemprosesan informasi (information-processing), metodologis (methodological), moderat (moderate), mengikuti Piaget (piagetian), post epistemologis (post epistemological), prakmatis (pragmatic), radikal (radical), rasional (rational), realis (realist), sosial (social), dan sosiohistoris (sociohistorical).

- Bredo (2000) membagi konstruktivisme dalam empat kelompok besar, yaitu konstruktivisme individual dan idealis (individual idealistconstructivism), konstruktivisme individual dan realis (individual realist constructivism), konstruktivisme sosial dan idealis (social idealist constructivism), dan 
konstruktivisme sosial dan realis (social realist constructivism).

- Geelan (1997) menyatakan bahwa ada empat variasi konstruktivisme, yaitu: konstruktivisme sosial-objektif (socialobjectivist constructivism), konstruktivisme sosial-relatif (socialrelativist constructivism), konstruktivisme personal-relatif (personal-relativist constructivism), dan konstruktivisme personal objektif (personal-objectivist constructivism).

- Matthews (2000) mengidentifikasi ada tiga macam konstruktivisme, yaitu: konstruktivisme pendidikan (educational constructivism), konstruktivisme filosofis (philosophical constructivism), dan konstruktivisme sosiologis (sociological constructivism).

Timbulnya variasi dalam konstruktivisme memang sangat dimungkinkansebab konstruktivisme merupakan suatu teori yang baru sehingga masih terus berkembang. Sebagaimana telah diungkapkan di muka, variasi dalam konstruktivisme bisa menyulitkan pembaca pemula untuk memahami posisi penulis. Salah satu strategi untuk memahami variasi konstruktivisme adalah dengan menggunakan bagan klasifikasi dikhotomi (Widodo, 2004) yang mengelompokan konstruktivisme berdasarkan tempat terjadinya konstruksi (personal atau sosial) dan tingkat objektivitas hasil pengkonstruksian (objektif atau relatif). Perlu diingat bahwa pengklasifikasian ini bukan pengklasifikasian orang melainkan klasifikasi ide (lihat Gambar 2).

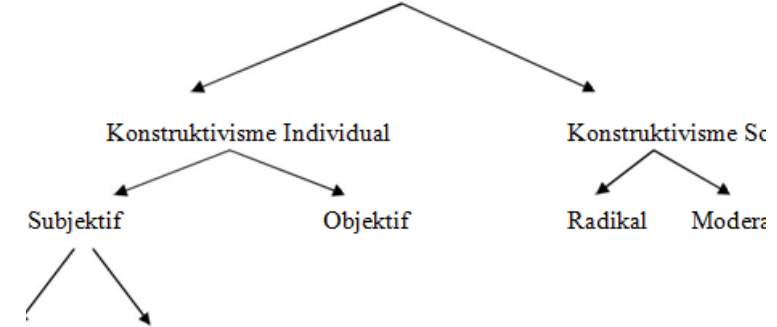

\section{Gambar 2 Klasılıkası alknotomi konstruktivisme (Widodo, 2004: 24)}

\section{Konstruktivisme individual}

Konstruktivisme-individual

berpendapat bahwa pengetahuan bersifat individual. Setiap individu mengkonstruk pengetahuan berdasarkan pengalaman pribadi masing-masing individu. Karena tidak ada individu yang memiliki pengalaman yang sama persis, maka pengetahuan yang dimiliki setiap orang juga berbeda. Berdasarkan tingkat objektifitas pengetahuan yang dikonstruk, konstruktivisme-individual dapat dibagi menjadi dua kelompok, yaitu konstruktivisme individual-subjektif dan konstruktivisme individual-objektif.

Konstruktivisme individual-subjektif berpendapat bahwa pengetahuan bukanlah representasi objektif fenomena alam. Pengetahuan merupakan hasil proses konstruksi orang terhadap fenomena alam. Pengetahuan merupakan sebuah proses adaptasi sehingga pengetahuan seseorang tidak stabil tetapi terus-menerus berubah. Dalam kelompok konstruktivisme individualsubjektif ada lagi variasi lanjut, yaitu kelompok yang radikal, misalnya von Glasersfeld (1993) dan kelompok yang lebih moderat.

Konstruktivisme individual-objektif berpendapat bahwa pengetahuan adalah konstruksi individu. Meskipun demikian mereka tidak setuju kalau dikatakan bahwa pengetahuan itu sepenuhnya subjektif. Kelompok ini berpendapat bahwa ada konsep yang "benar" yang menjadi rujukan bagi siswa dalam belajar. 


\section{Konstruktivisme sosial}

Kelompok ini menyatakan bahwa pengetahuan merupakan hasil konstruksi bersama, oleh karena itu pengetahuan selalu terpengaruh oleh kekuatan sosial di mana pengetahuan itu dikonstruk. Ada dua varian konstruktivisme sosial, yaitu konstruktivisme sosial-radikal dan konstruktivisme sosialmoderat.

Konstruktivisme sosial-radikal berpendapat bahwa pengetahuan ilmiah sifatnya mirip dengan fenomena sosial. Pengetahuan ilmiah merupakan produk wacana sosial dan karenanya merupakan konsensus masyarakat. Oleh karena itu pengetahuan haruslah dinilai dengan menggunakan kaidah-kaidah sosiologi (Phillips, 1997). Konstruktivisme sosialmoderat juga berpendapat bahwa pengetahuan merupakan konstruksi sosial. Namun demikian kelompok ini tidak setuju dengan pendapat bahwa pengetahuan hanyalah konstruksi sosial. Konstruktivisme sosial-moderat berpandangan bahwa ada fakta yang merupakan konstruksi sosial namun ada juga fakta yang merupakan fakta alamiah (Bredo, 2000).

\section{Prinsip-prinsip dasar konstruktivisme}

Sebagaimana telah diuraikan, konstruktivisme ternyata sangat banyak variasinya. Oleh karena itu cukup sulit juga untuk mengidentifikasi prinsip-prinsip dasar konstruktivisme yang mewakili berbagai variasi tersebut. Oleh karena itu prinsipprinsip konstruktivisme yang diuraikan berikut merupakan prinsip-prinsip menurut konstruksi penulis dan tidak dimaksudkan sebagai prinsip yang harus diterima semua orang.

\section{Pandangan konstruktivisme tentang pengetahuan}

Salah satu permasalahan mendasar dalam konstruktivisme adalah pandangan tentang ilmu. Berdasarkan sejumlah literatur, penulis menyimpulkan ada tiga prinsip penting tentang ilmu, menurut konstruktivisme: 1) Pengetahuan adalah konstruksi manusia; 2) Pengetahuan merupakan konstruksi sosial; dan 3) Pengetahuan bersifat tentatif.

- Pertama, pengetahuan merupakan hasil konstruksi manusia dan bukan sepenuhnya representasi suatu fenomena atau benda.

Pengetahuan bukanlah representasi objektif fenomena alam akan tetapi pengetahuan merupakan konstruksi manusia. Fenomena atau obyek memang bersifat obyektif, namun observasi dan interpretasi terhadap suatu fenomena dipengaruhi subyektivitas pengamat (von Glasersfeld, 1998).

- Kedua, pengetahuan merupakan hasil konstruksi sosial

Pengetahuan terbentuk dalam suatu konteks sosial tertentu. Oleh karena itu pengetahuan terpengaruh kekuatan sosial (ideologi, agama, politik, kepentingan suatu kelompok, dsb) dimana pengetahuan itu terbentuk.

- Ketiga, pengetahuan bersifat tentatif

Sebagai konstruksi manusia, kebenaran pengetahuan tidaklah mutlak tetapi bersifat tentatif dan senantiasa berubah. Sejarah IPA telah membuktikan bahwa sesuatu yang diyakini "benar" pada suatu masa ternyata "salah" di masa selanjutnya.

\section{Pandangan konstruktivisme tentang belajar dan mengajar}

Sebagai konsekuensi dari ketiga prinsip dasar sebagaimana diuraikan di atas, konstruktivisme juga mempunyai pandangan tentang belajar dan mengajar. Berdasarkan sejumlah literatur tentang konstruktivisme, Widodo (2004) mengidentifikasi lima hal penting berkaitan dengan belajar dan mengajar. 
- Pertama, pembelajar telah memiliki pengetahuan awal

Tidak ada pembelajar yang otaknya benar-benar kosong. Pengatahuan awal yang dimiliki pembelajar memainkan peran penting pada saat dia belajar tentang sesuatu hal yang ada kaitannya dengan apa yang telah diketahui.

- Kedua, belajar merupakan proses pengkonstruksian suatu pengetahuan berdasarkan pengetahuan yang telah dimiliki

Pengetahuan tidak dapat ditransfer dari suatu sumber ke penerima, namun pembelajar sendirilah yang mengkonstruk pengetahuan.

- Ketiga, belajar adalah perubahan konsepsi pembelajar

Karena pembelajar telah memiliki pengetahuan awal, maka belajar adalah proses mengubah pengetahuan awal siswa sehingga sesuai dengan konsep yang diyakini "benar" atau agar pengetahuan awal siswa bisa berkembang menjadi suatu konstruk pengetahuan yang lebih besar.

- Keempat, proses pengkonstruksian pengetahuan berlangsung dalam suatu konteks sosial tertentu.

Sekalipun proses pengkonstruksian pengetahuan berlangsung dalam otak masing-masing individu, namun sosial memainkan peran penting dalam proses tersebut sebab individu tidak terpisah dari individu lainnya.

- Kelima, pembelajar bertanggung jawab terhadap proses belajarnya. Guru atau siapapun tidak dapat memaksa siswa untuk belajar sebab tidak ada seorangpun yang bisa "mengatur" proses berpikir orang lain. Guru hanyalah menyiapkan kondisi yang memungkinkan siswa belajar, namun apakah siswa benar-benar belajar tergantung sepenuhnya pada diri pembelajar itu sendiri.

\section{Penerapan prinsip konstruktivime dalam pembelajaran}

Banyaknya variasi konstruktivisme juga menimbulkan kriteria yang beragam tentang bagaimana lingkungan pembelajaran yang konstruktivis. Taylor dan Fraser (1991) dan Aldridge, Fraser, Taylor dan Chen (2000) menyatakan bahwa lingkungan pembelajaran yang konstruktivis mempunyai lima ciri, yaitu: Autonomi (keterlibatan siswa dalam mengontrol belajarnya; Pengetahuan awal (pemanfaatan pengetahuan awal siswa dalam pembelajaran); Negosiasi (peran siswa dalam penentuan tujuan dan konsensus lainnya); Keberpusatan pada siswa (keterkaitan anatara pengalaman belajar dengan kepentingan siswa); dan Ketidakpastian (penilaian kritis siswa terhadap pembelajaran. Beberapa ahli lain, misalnya Gerstenmaier dan Mandl (1995), Vosnoiadou, Ioannides, Dimitrakopoulou dan Papademitrou (2001), dan Labudde (2000) juga memberikan kriteria tentang lingkungan pembelajaran yang konstruktivis dengan penekanan yang sedikit berbeda.

Analisis terhadap sejumlah kriteria dan pendapat sejumlah ahli dapat disarikan bahwa lingkungan pembelajaran yang konstruktivis pada dasarnya mencakup lima unsur penting (Widodo, 2004), yaitu:

1). Memperhatikan dan memanfaatkan pengetahuan awal siswa Kegiatan pembelajaran ditujukan untuk membantu siswa dalam mengkonstruksi pengetahuan. Siswa didorong untuk mengkonstruksi pengetahuan baru dengan memanfaatkan pengetahuan awal yang telah dimilikinya. Oleh karena itu pembelajaran harus memperhatikan pengetahuan awal siswa dan memanfaatkan teknik-teknik untuk mendorong agar terjadi perubahan konsepsi pada diri siswa.

2). Pengalaman belajar yang autentik dan bermakna Segala kegiatan yang dilakukan di dalam pembelajaran 
dirancang sedemikian rupa sehingga bermakna bagi siswa. Oleh karena itu minat, sikap, dan kebutuhan belajar siswa benar-benar dijadikan bahan pertimbangan dalam merancang dan melakukan pembelajaran. Hal ini dapat terlihat dari usaha-usaha untuk mengaitkan pelajaran dengan kehidupan sehari-hari, penggunaan sumber daya dari kehidupan sehari-hari, dan juga penerapan konsep.

3). Adanya lingkungan sosial yang kondusif, Siswa diberi kesempatan untuk bisa berinteraksi secara produktif dengan sesama siswa maupun dengan guru. Selain itu juga ada kesempatan bagi siswa untuk bekerja dalam berbagai konteks sosial.

4). Adanya dorongan agar pembelajar bisa mandiri. Siswa didorong untuk bisa bertanggung jawab terhadap proses belajarnya. Oleh karena itu siswa dilatih dan diberi kesempatan untuk melakukan refleksi dan mengatur kegiatan belajarnya.

5). Adanya usaha untuk mengenalkan siswa tentang dunia ilmiah.IPA bukan hanya produk (fakta, konsep, prinsip, teori), namun juga mencakup proses dan sikap. Oleh karena itu pembelajaran IPA juga harus bisa melatih dan memperkenalkan siswa tentang "kehidupan" ilmuwan.

\section{Urutan pembelajaran yang konstruktivis}

Variasi konstruktivisme juga tercermin dari beragamnya pendapat tentang bagaimana urutan pembelajaran yang konstruktivis. Kalau pada mulanya Driver (1989) mengajukan suatu urutan bagaimana pembelajaran yang konstruktivis, berikutnya muncul berbagai pendapat tentang urutan tersebut (Lawson, 1989; Nunez-Oviedo, Clement, \& Rea-Ramirez, 2002). Seperti halnya pendapat tentang lingkungan pembelajaran yang konstruktivis, setiap ahli mempunyai penekanan yang berbeda tentang tahapan yang dinilai penting dan dengan demikian dibuat relatif rinci.

Sekalipun urutan pembelajaran yang diajukan beberapa ahli mempunyai beberapa variasi, namun sesungguhnya terdapat banyak kesamaan. Hal ini menunjukkan bahwa sekalipun setiap ahli mungkin mempunyai penekanan tersendiri, namun ada sejumlah prinsip dasar yang disetujui bersama. Urutan pembelajaran konstruktivis bahkan mempunyai banyak kesamaan dengan urutan pembelajaran "membangun konsep/membangun pengetahuan" sebagaimana dikemukakan oleh Oser dan Patry (1990) sekalipun mereka tidak menyatakan urutan pembelajaran yang konstruktivis. Hal ini menunjukkan bahwa urutan pembelajaran yang dikemukakan oleh para pendukung konstruktivisme ternyata konsisten dengan prinsip kognitif secara umum.

Berdasarkan sejumlah literatur
tentang tahapan pembelajaran konstruktivis terlihat bahwa pembelajaran yang konstruktivis terdiri dari 5 tahapan yang saling berurutan (Widodo, 2004), yaitu:

1). Pendahuluan: Tahap penyiapan pembelajar untuk mengikuti kegiatan pembelajaran.

2). Eksplorasi: Tahap pengidentifikasian dan pengaktifan pengetahuan awal pembelajar.

3). Restrukturisasi: Tahap restrukturisasi pengetahuan awal pembelajar agar terbentuk konsep yang diharapkan.

4). Aplikasi: Tahap penerapan konsep yang telah dibangun pada konteks/kondisi yang berbeda ataupun dalam kehidupan sehari-hari.

5). Review dan Evaluasi: Tahap peninjauan kembali apa yang telah terjadi pada diri pembelajar berkaitan dengan suatu konsep/pembelajaran. 


\section{SIMPULAN DAN SARAN}

Konstruktivisme merupakan sebuah teori pembelajaran yang relatif baru dan masih terus berkembang sehingga senantiasa muncul variasi-variasi baru atau paling tidak istilah-istilah baru dalam konstruktivisme yang kadang membingungkan. Sebagai sebuah ilmu hal ini merupakan dinamika yang menguntungkan namun bagi orang yang mempelajari (terutama pemula) kadang menimbulkan kesulitan. Oleh karena itu sesungguhnya tidak begitu tepat apabila para guru hanya dituntut untuk menerapkan prinsip-prinsip konstruktivisme dalam pembelajarannya tanpa adanya bimbingan yang memadai.

Hal inilah yang mungkin menjadi salah satu penyebab adanya kesenjangan antara popularitas konstruktivisme dalam literatur dan penelitian dengan penerapannya dalam praktek pembelajaran di dalam kelas. Untuk menerapkan prinsip-prinsip konstruktivisme guru memerlukan pemahaman yang mantap (yang sayangnya belum mereka miliki sepenuhnya) dan juga dukungan serta pengalaman menyaksikan pembelajaran dengan konstruktivisme (yang sayangnya juga jarang mereka peroleh).

Oleh karena itu, apabila guru memang diharapkan untuk dapat menerapkan prinsipprinsip konstruktivisme dalam pembelajarannya mereka perlu mendapatkan pembekalan tentang prinsip-prinsip dasar konstruktivisme, bagaimana penerapan prinsip-prinsip tersebut dalam pembelajaran, dan latihan menerapkan prinsip konstruktivisme dalam pembelajaran. Pembekalan dan latihan khusus ini mutlak diperlukan sebab guru-guru yang ada saat ini umumnya belum mendapatkan bekal pengetahuan dan keterampilan yang memadai untuk menerapkan prinsip-prinsip konstruktivisme sebab pada saat mereka belajar di perguruan tinggi konstruktivis belum banyak disosialisasikan. Apabila hal ini tidak dilakukan harapan agar pembelajaran memperhatikan prinsip-prinsip konstruktivisme sebagaimana yang dinyatakan dalam kurikulum hanya menjadi slogan yang tidak bermakna.

\section{DAFTAR PUSTAKA}

Aldridge, J. M., Fraser, B. J., Taylor, P. C., \& Chen, C. (2000). Constructivist learning environments in a crossnational study in Taiwan and Australia. International Journal of Science Educational, 22(1), 37-55.

Bredo, E. (2000). Reconsidering social constructivism: The relevance of George Herbert Mead's interactionism. In D. C. Phillips (Ed.), Constructivism inEducation: Opinion and Second Opinions on Controversial Issues.Chicago: The National Society for the Study of Education.

Depdiknas. (2003a). Kurikulum 2004: Standar Kompetensi Mata PelajaranBiologi Sekolah Menengah Atas dan Madrasah Aliyah. Jakarta: PusatKurikulum Balitbang Depdiknas. 